\title{
Cutaneous leishmaniasis as an increasing threat for Iranian travellers attending religious ceremonies
}

\author{
Mehrzad Saraei, ${ }^{1,2}$ Bibi R.H. Farash ${ }^{3,4}$ and Elham Hajialilo ${ }^{2,5}$
}

${ }^{1}$ Medical Microbiology Research Center, Qazvin University of Medical Sciences, Qazvin, Islamic Republic of Iran. ${ }^{2}$ Department of Parasitology and Mycology, Qazvin University of Medical Sciences, Qazvin, Islamic Republic of Iran (Correspondence to: E. Hajialilo: e.hajialilo@gmail.com). ${ }^{3}$ Cutaneous Leishmaniasis Research Center, School of Medicine, Mashhad University of Medical Sciences, Islamic Republic of Iran. ${ }^{4}$ Department of Parasitology and Mycology, School of Medicine, Mashhad University of Medical Sciences, Mashhad, Islamic Republic of Iran. ${ }^{5}$ Student Research Committee, Qazvin University of Medical Sciences, Qazvin, Islamic Republic of Iran.

\begin{abstract}
Background: The Islamic Republic of Iran is one of the most important endemic foci of cutaneous leishmaniasis in the world. Annually, a large number of Iranian Shia pilgrims travel to Iraq from this area in order to participate in one of their most important religious ceremonies. This trip has coincided with the seasonal activity of sand flies in recent years. So, cutaneous leishmaniasis could be a serious threat for pilgrims on these trips.
\end{abstract}

Aims: To report cases of cutaneous leishmaniasis among Iranian Shia pilgrims attending a religious ceremony in Iraq during 2017.

Methods: Sixteen patients were referred to our laboratory in the Department of Parasitology and Mycology at Qazvin University of Medical Sciences. Dermal scrapings and stained slides prepared of skin lesions were used to morphological diagnosis. DNA extraction and PCR amplification were optimized to identification of Leishmania species.

Results: All of the patients were infected with cutaneous leishmaniasis in microscopic survey. L. major was detected by molecular approach. The number of lesions observed in patients were $1(31 \%), 2(25 \%)$, and $\geq 3(44 \%)$.

Conclusions: Since a large number of Shia Muslims participate in the annual religious ceremonies, serious measures must be taken to prevent the disease.

Keywords: cutaneous leishmaniasis, Islamic Republic of Iran, Mehran, pilgrims, travelers

Citation: Saraei M; Farash BRH; Hajialilo E. Cutaneous leishmaniasis as an increasing threat for Iranian travellers attending religious ceremonies. East Mediterr Health J. 2021;27(1):90-95. https://doi.org/10.26719/emhj.20.062

Received: 15/06/19; accepted: 10/09/19

Copyright (C) World Health Organization (WHO) 2021. Open Access. Some rights reserved. This work is available under the CC BY-NC-SA 3.0 IGO license (https://creativecommons.org/licenses/by-nc-sa/3.o/igo).

\section{Introduction}

Leishmaniasis is an important parasitic disease with a diverse spectrum of clinical syndromes, such as cutaneous leishmaniasis (CL), and visceral leishmaniasis (VL) (1). Some cutaneous lesions can be self-healing. CL considered as an important public health problem when the lesions are presented for a long period, with persistent ulcers, and secondary bacterial infections causing heavy treatment cost and complications of drug therapy (2-4). Etiologic agent of CL is species of leishmania genus, an obligate intracellular protozoan parasite of mononuclear phagocytes in vertebrate hosts (5). Up to now, more than 30 species of Leishmania have been detected, At least 20 species of parasite can be infected humans $(6,7)$. Female phlebotomine sand flies are vector of the parasite in tropical and subtropical regions. CL are distributed about $95 \%$ in South and Central America, Mediterranean, Middle East and Central Asia $(8,9)$. The disease was reported from more than 98 countries in the world, in which the most important endemic foci in old world including; Afghanistan, Algiers, Islamic Republic of Iran, Saudi Arabia and Syria, and in the new world, Brazil, Colombia and Peru countries $(10,11)$. CL is common in Islamic Republic of
Iran with both shape of Anthroponotic Cutaneous Leishmaniasis (ACL) and Zoonotic Cutaneous Leishmaniasis (ZCL), caused by Leishmania tropica and Leishmania major, respectively (12). Up to now, $C L$ is endemic in 17 provinces of 31 provinces of Islamic Republic of Iran, with the majority of ZCL (11). In spite of, the prevalence of human parasitic infections, especially soil transmitted helminthes have remarkably decreased in Islamic Republic of Iran (13), but ZCL is expanding in the country and new foci of infection have been reported in recent years (14-19). It seems that migrating rodent reservoirs to new areas is a possible major cause of wide spreading of $C L$ in Islamic Republic of Iran. Annually, about 20,000 of new cases of $\mathrm{CL}$ are recorded in the country, in which the real number of patients are multiplied estimated (20). Also, CL epidemic have been reported from Islamic Republic of Iran in the recent decades $(21,22)$.

Residents of non-endemic areas of CL in Islamic Republic of Iran are the population at risk for this disease when travel to endemic areas during seasonal activity of sand flies. Ilam province is one of the 31 provinces of Islamic Republic of Iran, and also the province is one of important endemic foci of CL that is located in west of Islamic Republic of Iran and in the neighborhood of 
Iraq. Mehran is a county in west of the province and categorized as hyper endemic areas of CL in the country $(14,23-25)$. This county is the shortest departure way from Islamic Republic of Iran to Karbala city in Iraq. Karbala is a holy city for Shia Muslims, in which a large number of individuals travel to this city for participate in one of the most magnificent religious ceremonies called Arbaeen Husayni. In next years, this massive pilgrimage trip will be coincide with peak seasonal activities of sand flies, therefore, there is an increasing risk of CL for people who will be participating in the pilgrimage tripe.

\section{Methods}

The cross-sectional study was performed from January to April 2018. Sixteen patients were referred to laboratory of Parasitology and Mycology at Qazvin University of Medical Sciences, Qazvin, Islamic Republic of Iran. Except for a woman from Qazvin (a non-endemic region for $\mathrm{CL}$ ) who was among the pilgrims to Karbala, the rest of patients were from Bus Company employees of Qazvin city. These people were responsible for transferring of pilgrims from Mehran to border regions of Islamic Republic of Iran and Iraq. The place of sleep and rest of these people was located in a building on the outskirts of the city of Mehran where they had been stayed for 20 days. Mehran is a city in Ilam province located in west of Islamic Republic of Iran.

Microscopic surveys were used to through of patients. Initially, cutaneous lesions were disinfected by $70 \%$ ethanol. Two to three smears were prepared of each lesion. The smears were fixed with methanol and then stained by Giemsa stain. The slides were surveyed under light microscopy to found Leishman bodies (amastigotes) at 1000× magnification.

DNA extraction was performed by obtained slides of the patients. The immersion oil on each smear was cleaned with xylol, and then the entire smear was scraped into a $1.5 \mathrm{ml}$ microcentrifuge tube. DNA of the smear was extracted by blood and tissue Kit, Qiagen (QIAamp DNA mini kit) according to the manufacturer's recommended protocol. PCR was performed, targeting the kDNA pattern of leishmania, L. major / 615 base pair (bp) and for L. tropica / 744 bp, by specific primers. Conventional PCR was carried out in a $25 \mu$ lotal reaction volume. The reaction containing, $5 \mu \mathrm{M}$ of template DNA, $0.1 \mu \mathrm{M}$ of each primer and $\mathrm{MgCl} 2$ (0.5 to $4 \mu \mathrm{M}$ ) (26). Negative and positive controls were used to monitoring all of reactions. After electrophoresis, The PCR product was stained by ethidium bromide and specific bands were seen under UV light.

\section{Ethics approval and consent to participate}

The local ethics committee ruled that no formal ethics approval was required in this particular case. The cost of testing was free for the patients. The results of the tests were provided to the patients and they were introduced to university medical center for treatment.

Photographs were taken from the patients' wounds with their oral permission. Written consent of the patient's face in the figure 3 was considered in the consent form.

\section{Results}

Leishmania bodies were microscopically diagnosed in all 16 patients referred to our laboratory (Figure 1). The microscopic results were confirmed by molecular approach; therefore, L. major species was detected among all specimens (Figure 2). The age range of patients was 28-60 years. The incubation periods of CL in our patients were not definitely cleared, but the onset of the first signs of disease (boil) appeared two weeks to two months after departure from the area and arrival to the mentioned habitat, however, an incubation time of almost 6 months was observed in one patient. A maximum of six lesions was observed in one patient. Frequency distribution for the number of lesions were one wound (31\%; 5/16), two wounds $(25 \% ; 4 / 16)$, and three and more $(44 \% ; 7 / 16)$. A rare case of CL was seen in a patient who had two ulcers, one in the upper eyelid, and another in the middle and front of the neck (Figure 3). Surprisingly, a patient had self-medication by burning lesions with the heat of cigarette (Figure 4). Only one of the patients was female pilgrim who had returned from the pilgrimage ceremony in Karbala. None of the patients had previous history of CL.

\section{Discussion}

Traveling to endemic areas of vector-borne diseases is a risk factor for people who travel from non-endemic areas. $\mathrm{CL}$ is a sand flies-borne disease which has been reported among travelers entered the endemic foci of this protozoan parasitic disease (26-30). In our study, these infections occurred among the bus company employees who were responsible for transporting the Arbaeen pilgrims from Mehran to the border areas between Islamic Republic of Iran and Iraq and vice versa. The location for the deployment of these people was in a building in the margin of Mehran city where it is considered as an important endemic focus of ZCL in the west of Islamic Republic of Iran (23).

Figure 1 Leishmania tropica amastigotes in an intact macrophage (red arrow) and extracellular (blue arrow) from a skin lesion of a traveler who infected with the parasite in Islamic Republic of Iran-Iraq border. (Magnification x100o)

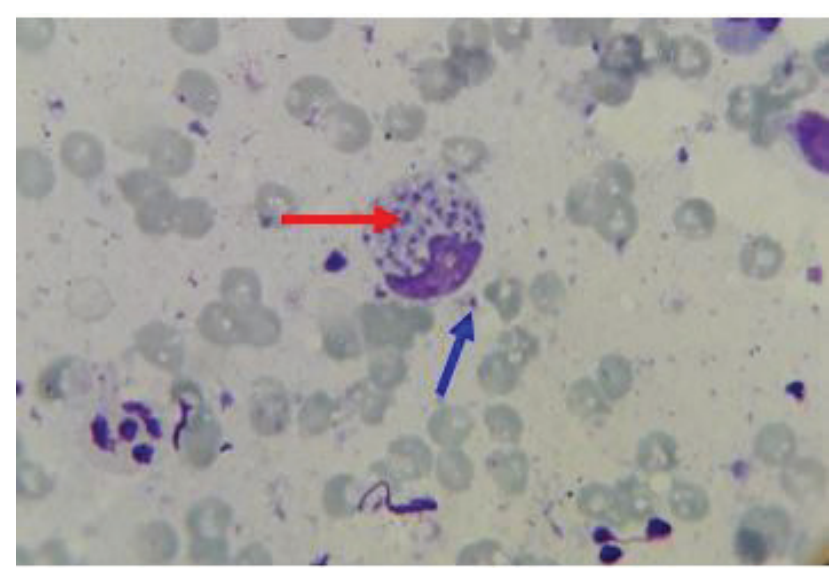



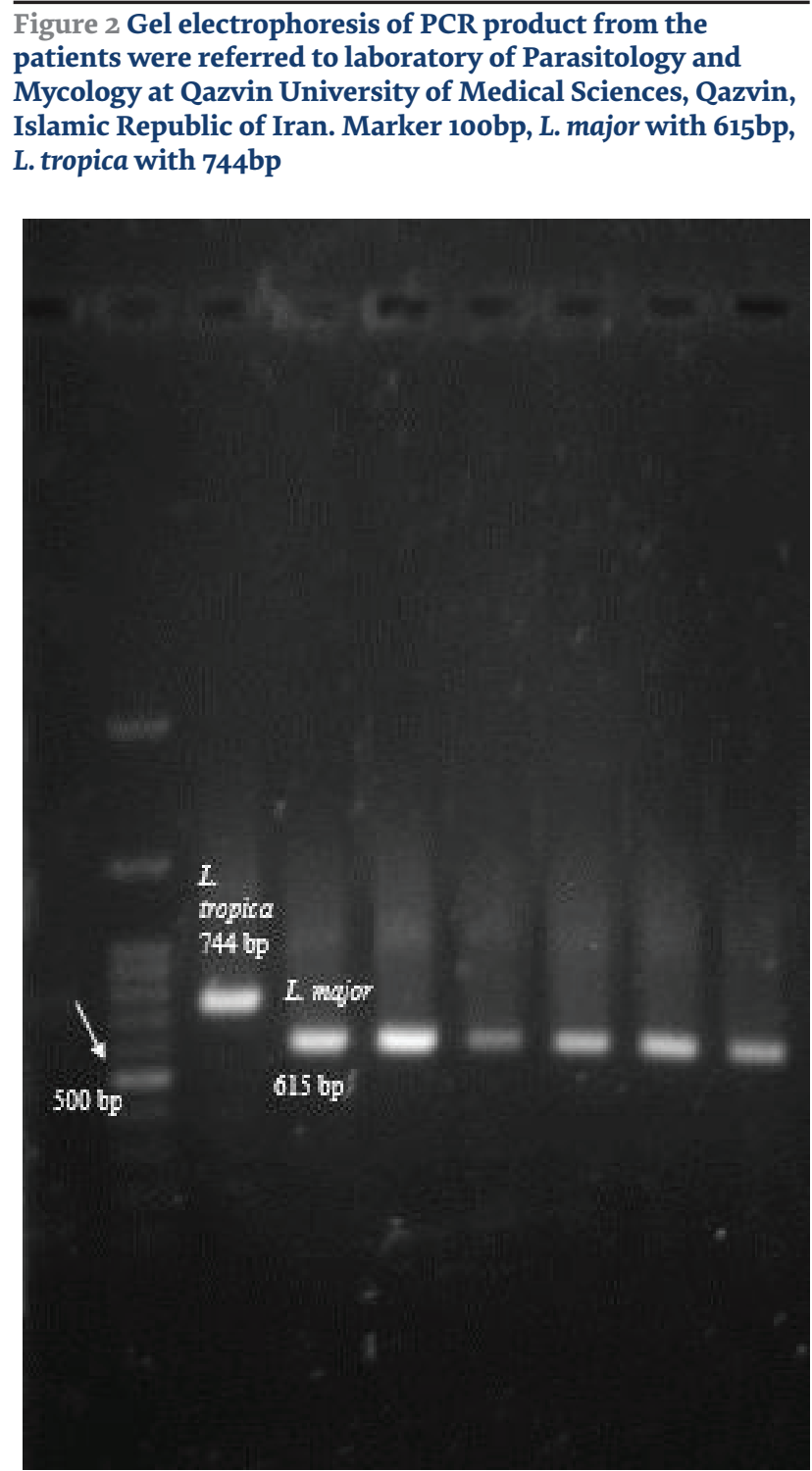

In the present study, L. major was the only species of Leishmania genus which was isolated from the patients and identified by PCR amplification, a finding similar to the results reported in a previous study (23). The findings indicated that, the area is a ZCL foci in Islamic Republic of Iran and also showed that human infections with Leishmania have zoonotic origin in this region. Reservoirs of the parasite in west of Islamic Republic of Iran are rodents family of Gerbilidae, such as Rhombomys opimus, Meriones libycus, Tatera indica and Nesokia indica, as well as T. indica which is categorized as a main reservoir $(28,29)$. Phelobotumus Papatasi was introduced as a major vector to leishmania in the region and neighboring regions (30).

Evidences showed that the CL is increasing in the Mehran area in the recent years (2016) in 92 patients (23). It could be a potential risk for Iranian religious travelers who are eager to participate in Arbaeen Husayni ceremony in Iraq in future years. This ceremony is one of the most important religious programs of Shia Muslims. The Muslims are greatly eager to travel to these areas. The
Figure 3 Cutaneous leishmaniasis caused by L. major in a patient who travel from a non-endemic area to an endemic area of Ilam province located in west of Islamic Republic of Iran. He had two ulcers, A; one in the upper eyelid, B; another ulcer in the middle and front of the neck
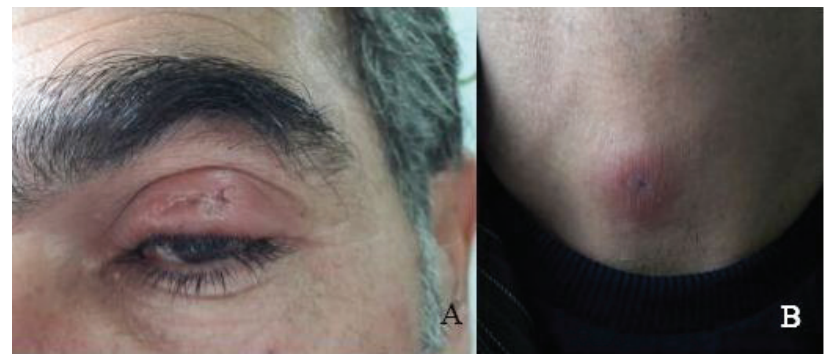

The patient gave written consent to use the photograph of his face.

religious travelers are called pilgrims. One of the most holy cities to the Muslims is Karbala city in Iraq, in which the region is the burial ground of the third Imam of the Shiites (Imam Husayn). One of the most important days to commemorate Imam Husayn is the $40^{\text {th }}$ day after his martyrdom known as Arbaeen. Around this time, massive crowd of Shia Muslims travel to Karbala every year (31). Mehran is the shortest way to the Iranian pilgrims and most pilgrims go to Karbala from this route. In 2017, the transfer of some Iranian pilgrims to entrance place of Islamic Republic of Iran-Iraq border region was carried out by the employees of the Bus Company of Qazvin. The pilgrims were settled in a building around the city of Mehran where it was neighboring the rodent habitat and

Figure 4 Cutaneous leishmaniasis caused by L. major at the foot of a patient who travel from a non-endemic area to an endemic area of Ilam province located in west of Islamic Republic of Iran. He had done a self-medication by burning lesions with the heat of cigarette

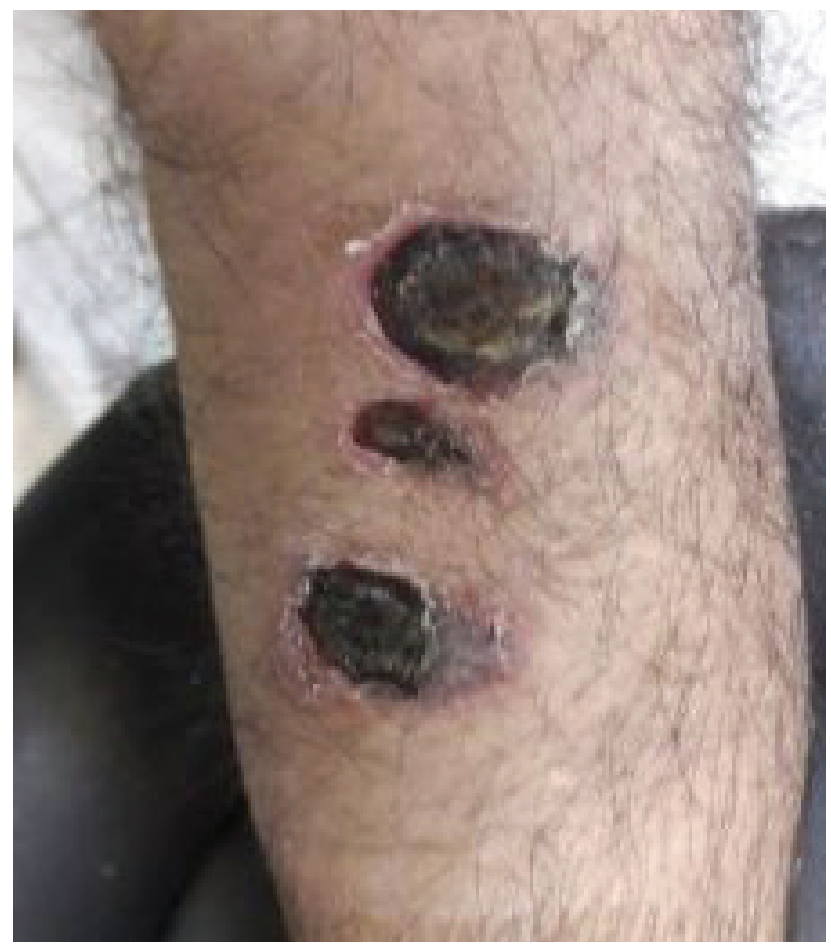


vectors of leishmaniasis. Therefore, they were at risk of CL. A total number of sixteen individuals were referred to our laboratory. Other patients may have been referred to other laboratories or had small lesions and preferred not to visit a doctor for their treatment.

In this study, only one of the patients was among Arbaeen pilgrims. All patients were free of immune deficiency and lived in Qazvin which is considered as a non-endemic region for CL. However, the number of pilgrims was much higher than the persons involved in transportation. Probably, low frequency of CL among the pilgrims is related to the short-term stop of few hours in comparison to one-month stay of staff in the area, so the pilgrims were at lower risk of sand fly bite.

It seems that the risk of CL will be an increasing threat for Iranian people involved in Arbaeen ceremony in future years, even CL could be threat to the pilgrims with short-term inhabitancy, because this religious trip will gradually coincide with the peak biting activity of sand flies in the study area. The ceremony is based on lunar months with 354 days in a year (355 days in the third year), whereas it is 365 days in a year according to solar (Shamsi) and AD calendars. Therefore, annual Arbaeen ceremony will occur 10 days earlier than the previous year, based on Shamsi and $\mathrm{AD}$ calendars. The ceremony was held on November 9, 2017 and will be held in 2018 on October 3oth. The second peak activity of sand flies in the west of Islamic Republic of Iran is around the end of summer to early autumn, so it is predicted that if essential preventive measures are not established within the next years, an outbreak of CL may occur. The eagerness of Shia Muslims for the religious trip is to that extent that even the risk of this parasitic disease cannot discourage the Muslims from travelling to these areas.

We conclude that $\mathrm{CL}$ has an increasing risk for Iranian pilgrims who would be participating in Arbaeen pilgrimage trips in the future years. Therefore, it is recommended that the health care providers take serious preventive measures for the coming years in order to secure good health condition of pilgrims. The study recommend that providing insect repellents can be useful to prevent CL infection among travelers for safe journeys in the future.

\section{Acknowledgement}

The authors sincerely thank the Vice Chancellor for Research of Qazvin University of Medical Sciences for facilitating the performance of the present study. We would like to appreciate the assistance offered by the colleagues at the Department of Parasitology and Mycology, Medical School, Qazvin University of Medical Sciences, and also, the Health Center of Qazvin. Thanks to Ms. Mahboobeh Sadeghi for preparation of the specimens. We thank Dr. Ali-Asghar Pahlevan for editing the final version of the English manuscript.

Funding: None.

Competing interests: None declared.

\section{La leishmaniose cutanée : une menace croissante pour les voyageurs iraniens qui se rendent en Iraq pour assister à une cérémonie religieuse}

\section{Résumé}

Contexte : La République islamique d'Iran est l'un des plus importants foyers d'endémie de leishmaniose cutanée (LC) au monde. Chaque année, un grand nombre de pèlerins chiites iraniens se rendent en Iraq depuis cette région afin de participer à une de leurs cérémonies religieuses les plus importantes. Ces dernières années, ce voyage a coïncidé avec l'activité saisonnière des phlébotomes. La LC pourrait donc représenter une grave menace pour les personnes qui entreprennent ce pèlerinage.

Objectifs : Signaler les cas de LC chez les pèlerins chiites iraniens ayant assisté à une cérémonie religieuse en Iraq en 2017.

Méthodes : Seize patients ont été orientés vers notre laboratoire au département de parasitologie et de mycologie de l'Université des Sciences médicales de Qazvin. Des prélèvements obtenus par grattage et des colorations de lames préparées à partir de lésions cutanées ont été utilisés pour le diagnostic morphologique. L'extraction d'ADN et l'amplification génique ont été optimisées pour l'identification des espèces du genre Leishmania.

Résultats: Une infection par des Leishmania a été diagnostiquée au microscope chez tous les patients. L. major a été détecté par approche moléculaire. Le nombre de lésions observées chez les patients était de 1 (31\%), 2 (25\%) et supérieure ou égale à 3 (44\%).

Conclusions : Puisqu'un grand nombre de musulmans chiites participent aux cérémonies religieuses annuelles, des mesures sérieuses doivent être prises pour prévenir la maladie. 


$$
\text { ماء الليشمانيات الجلدي كتهديد متزايد للمسافرين الإيرانيين الذين يجضرون المراسم الدينية في العراق، بلى بلى راضيه حسينى فراش، الهام حاجى عليلو }
$$

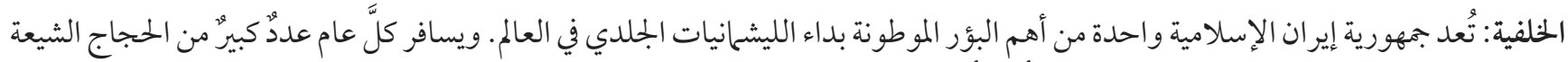

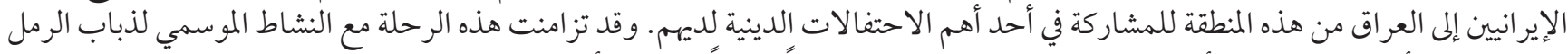

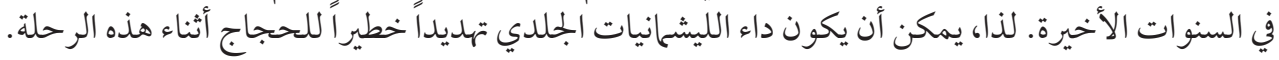

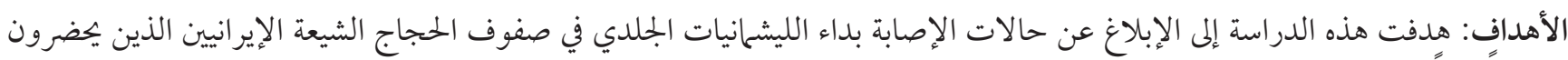

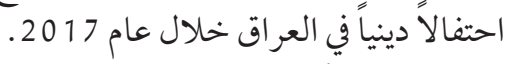

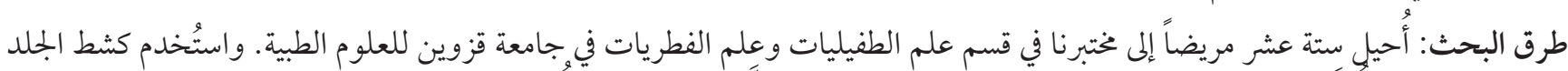

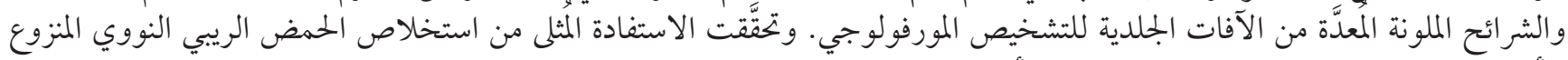

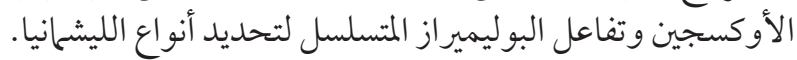

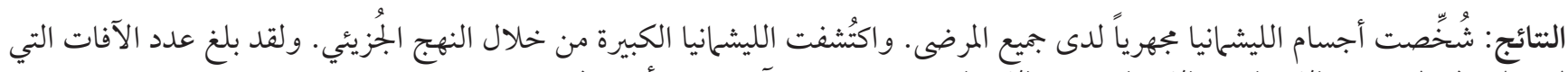

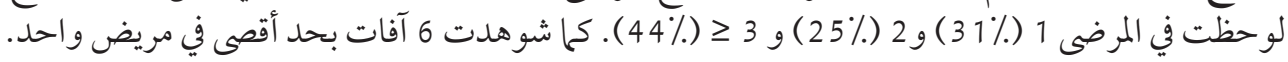

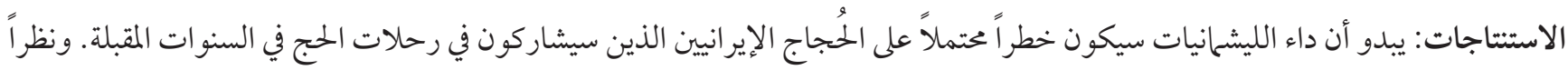

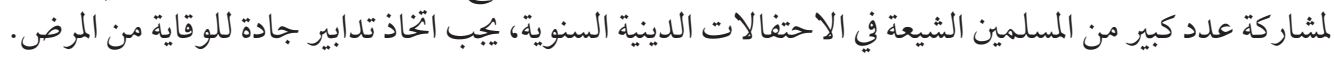

\section{References}

1. Desjeux P. The increase in risk factors for leishmaniasis worldwide. Trans R Soc Trop Med Hyg. 2001 May-Jun;95(3):239-43. http://dx.doi.org/10.1016/s0035-9203(01)90223-8 PMID:11490989

2. Dowlati Y. Cutaneous leishmaniasis: clinical aspect. Clin Dermatol. 1996 Sep-Oct;14(5):425-31. http://dx.doi.org/10.1016/o738081x(96)00058-2 PMID:8889320

3. Momeni A, Aminjavaheri M. Clinical picture of cutaneous leishmaniasis in Isfahan, Iran. Int J Dermatol. 1994 Apr;33(4):260-5. http://dx.doi.org/10.1111/j.1365-4362.1994.tbo1039.x PMID: 8021082

4. Brecelj M, Pikelj F, Gubensek, Anderluh G. Polymerase chain reaction as a diagnostictool for detecting Leishmania. Infection. 2000 Mar-Apr;28(2):111-3. http://dx.doi.org/10.1007/s150100050057 PMID:10782398

5. $\quad$ Alexander J, Russell DG. The interaction of Leishmania species with macrophages. Adv Parasitol. 1992;31:175-254. http://dx.doi. org/10.1016/s0065-308x(08)60022-6 PMID:1496927

6. Bates PA. Transmission of Leishmania metacyclic promastigotes by phlebotomine sand flies. Int J Parasitol. 2007 Aug;37(10):1097106. http://dx.doi.org/10.1016/j.ijpara.2007.04.003 PMID:17517415

7. Peacock SC, Seeger k, Harris D, Murphy L, Ruiz JC, Quail MA, et al. Comparative genomic analysis of three Leishmania species that cause diverse human disease. Nat Genet. 2007 Jul;39(7):839-47. http://dx.doi.org/10.1038/ng2053 PMID:17572675

8. Leishmaniasis. Geneva: World Health Organization; 2020 (http://www.who.int/news-room/fact-sheets/detail/leishmaniasis, accessed 24 March 2020).

9. Berens-Riha N, Fleischmann E, Pratlong F, Bretzel G, von Sonnenburg F, Löscher T, et al. Cutaneous leishmaniasis (Leishmania tropica) in a German tourist after travel to Greece. J Travel Med. 2009 May-Jun;16(3):220-2. http://dx.doi.org/10.1111/j.17088305.2008.00291.x. PMID:19538585

10. Alvar J, Vélez ID, Bern C, Herrero M, Desjeux P, Cano J, et al. Leishmaniasis worldwide and global estimates of its incidence. PLoS One. 2012;7(5):e35671. http://dx.doi.org/10.1371/journal.pone.0035671 PMID:22693548

11. Moradi M, Rassi Y, Abai RA, Ramazani AZ, Mohebali M, Rafizadeh S. Some epidemiological aspects of cutaneous leishmaniasis with emphasis on vectors and reservoirs of disease in the borderline of Iran and Iraq. J Parasit Dis. 2018;42(2):243-51. https://doi. org/10.1007/s12639-018-0991-1

12. Ghasemian M, Maraghi S, Samarbafzadeh AR, Jelowdar A, Kalantari M. The PCR-based detection and identification of the parasites causing human cutaneous leishmaniasis in the Iranian city of Ahvaz. Ann Trop Med Parasitol. 2011 Apr;105(3):209-15. http:// dx.doi.org/10.1179/136485911X12899838683520 PMID:21801499

13. Rokni M. The present status of human helminthic diseases in Iran. Ann Trop Med Parasitol. 2008 Jun;102(4):283-95. http://dx.doi. org/10.1179/136485908X300805 PMID:18510809

14. Askari A, Sharifi I, Aflatoonian MR, Babaei Z, Ghasemi Nejad Almani P, Mohammadi MA, et al. A newly emerged focus of zoonotic cutaneous leishmaniasis in South-western Iran. Microb Pathog. 2018 Aug;121:363-8. http://dx.doi.org/10.1016/j.micpath.2018.04.053 PMID:29709689 
15. Emami MM, Yazdi M, Nilforoushzadeh M. Emergence of cutaneous leishmaniasis due to Leishmania major in a new focus of central Iran. Trans R Soc Trop Med Hyg. 2009 Dec;103(12):1257-62. http://dx.doi.org/10.1016/j.trstmh.2009.04.020 PMID:19497606

16. Fazaeli A, Fouladi B, Sharifi I. Emergence of cutaneous leishmaniasis in a border area at south-east of Iran: an epidemiological survey. J Vector Borne Dis. 2009 Mar;46(1):36-42. PMID:19326706

17. Norouzinezhad F, Ghaffari F, Norouzinejad A, Kaveh F, Gouya MM. Cutaneous leishmaniasis in Iran: results from an epidemiological study in urban and rural provinces. Asian Pac J Trop Biomed. 2016;6(7):614-9. https://doi.org/10.1016/j.apjtb.2016.05.005

18. Razmjou S, Hejazy H, Motazedian MH, Baghaei M, Emamy M, Kalantary M. A new focus of zoonotic cutaneous leishmaniasis in Shiraz, Iran. Trans R Soc Trop Med Hyg. 2009 Jul;103(7):727-30. http://dx.doi.org/10.1016/j.trstmh.2008.12.013 PMID:19223055

19. Yaghoobi Ershadi MR, Akhavan AA, Abai MR et al. Epidemiological study in a new focus of cutaneous leishmaniasis in the Islamic Republic of Iran. East Mediterr Health J. 2004 Jul-Sep;10(4-5):688. PMID:16335665

20. Hashemi SN, Mohebali M, Mansouri P et al. Comparison of leishmanin skin test and direct smear for the diagnosis of cutaneous leishmaniasis. Acta Med Iran. 2011;49(3):136-41. PMID:21681699

21. Sharifi I, Aflatoonian M, Fekri A. An epidemic of cutaneous leishmaniasis in Baft district in Kerman Province and its probable causative risk factors. Iran J Epidemiol. 2008;4(1):53-8 (in Persian).

22. Sharifi I, Nakhaei N, Aflatoonian MR et al. Cutaneous leishmaniasis in Bam: A comparative evaluation of pre-and post-earthquake years (1999-2008). Iran J Public Health. 2011;40(2):49-56. PMID:23113072

23. Haddad MHF, Ghasemi E, Maraghi S, Tavala M. Identification of Leishmania species isolated from human cutaneous leishmaniasis in Mehran, Western Iran using nested PCR. Iran J Parasitol. 2016 Jan-Mar;11(1):65-72. PMID:27095970

24. Kassiri H, Sharifinia N, Jalilian M, Shemshad K. Epidemiological aspects of cutaneous leishmaniasis in Ilam province, west of Iran (2000-2007). Asian Pac J Trop Dis. 2012;2(Suppl 1):S382-6. https://doi.org/10.1016/S2222-1808(12)60186-8

25. Mokhtari M, Miri M, Nikoonahad A, Jalilian A, Naserifar R, Ghaffari HR et al. Cutaneous leishmaniasis prevalence and morbidity based on environmental factors in Ilam, Iran: Spatial analysis and land use regression models. Acta Trop. 2016 Nov;163:90-7. http://dx.doi.org/10.1016/j.actatropica.2016.08.002 PMID: 27496622

26. Fata A, Hoseini Farash BR, Mohajery M, Shamsian SA, Rezaee A, Yazdanpanah MJ. Anthroponotic cutaneous leishmaniasis in torghabeh-shandiz, a region with rural texture (a molecular study). Jundishapur J Microbiol. 2013;6(10):e8274. http://dx.doi. org/10.5812/jjm.8274

27. Larréché S, Launay G, Weibel Galluzzo C, Bousquet A, Eperon G, Pilo JE, et al. Cluster of zoonotic cutaneous leishmaniasis (Leishmania major) in European travelers returning from Turkmenistan. J Travel Med. 2013 Nov-Dec;20(6):400-2. http://dx.doi. org/10.1111/jtm.12065 PMID:24165385

28. Akhoundi M, Mohebali M, Asadi M, Mahmodi MR, Amraei K, Mirzaei A. Molecular characterization of Leishmania spp. in reservoir hosts in endemic foci of zoonotic cutaneous leishmaniasis in Iran. Folia Parasitol (Praha). 2013 Jul;60(3):218-24. http://dx.doi. org/10.14411/fp.2013.024 PMID:23951928

29. Javadian E, Dehestani M, Nadim A, Rassi Y., Tahvildar-bidruni Gh, Seyedi-Rashti MA, et al. Confirmation of Tatera indica (Rodentia: Gerbilldae) as the main reservoir host of zoonotic cutaneous leishmaniasis in the west of Iran. Iran J Public Health. 1998;27(1-2):55-60.

30. Kavarizadeh F, Khademvatan S, Vazirianzadeh B, Feizhaddad MH, Zarean M, et al. Molecular characterization of Leishmania parasites isolated from sandflies species of a zoonotic cutaneous leishmaniasis in Musiyan south west Iran. J Parasit Dis. 2017 Mar;41(1):274-81 http://dx.doi.org/10.1007/s12639-016-0792-3 PMID:28316425

31. Piggott M. 20 million Shia Muslims brave Isis by making pilgrimage to Karbala for Arbaeen. International Business Times. 29 November 2014 (https://www.ibtimes.co.uk/20-million-shia-muslims-brave-isis-by-making-pilgrimage-karbala-arbaeen-1476618, accessed 25 March 2020). 